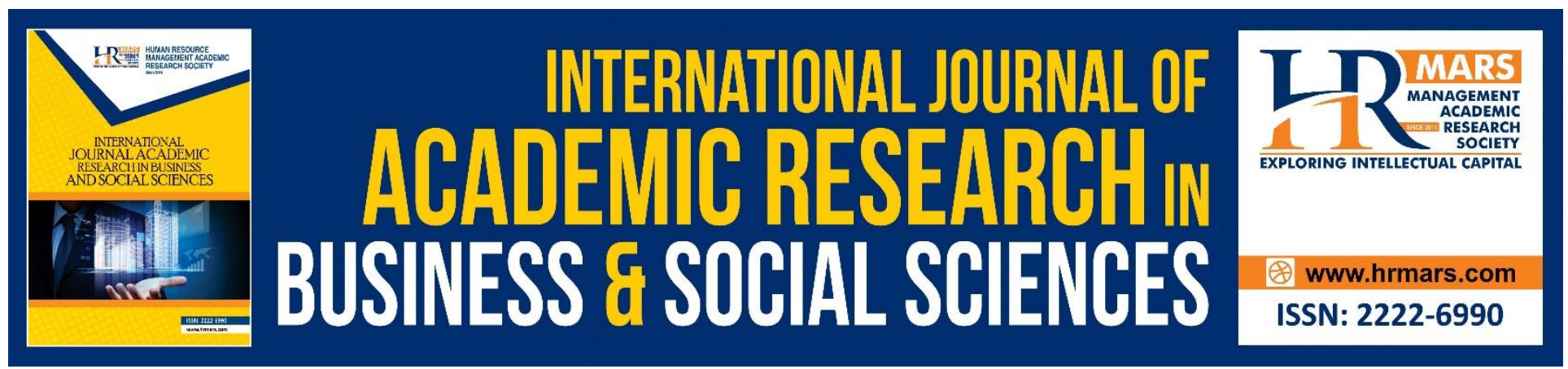

\title{
Managerial Ownership and Financial Performance of Listed Manufacturing Firms in Nigeria
}

\section{SAIDU, Sani Alhaji and GIDADO, Sani}

To Link this Article: http://dx.doi.org/10.6007/IJARBSS/v8-i9/4693

DOI: $\quad 10.6007 /$ IJARBSS/v8-i9/4693

Received: 13 August 2018, Revised: 09 Sept 2018, Accepted: 29 Sept 2018

Published Online: 15 October 2018

In-Text Citation: (Saidu \& Gidado, 2018)

To Cite this Article: Saidu, S. A., \& Gidado, S. (2018). Managerial Ownership And Financial Performance Of Listed Manufacturing Firms In Nigeria. International Journal Of Academic Research In Business And Social Sciences, 8(9), 1227-1243.

\section{Copyright: (c) 2018 The Author(s)}

Published by Human Resource Management Academic Research Society (www.hrmars.com)

This article is published under the Creative Commons Attribution (CC BY 4.0) license. Anyone may reproduce, distribute, translate and create derivative works of this article (for both commercial and non-commercial purposes), subject to full attribution to the original publication and authors. The full terms of this license may be seen

at: http://creativecommons.org/licences/by/4.0/legalcode

\section{Vol. 8, No. 9, September 2018, Pg. 1227 - 1243}




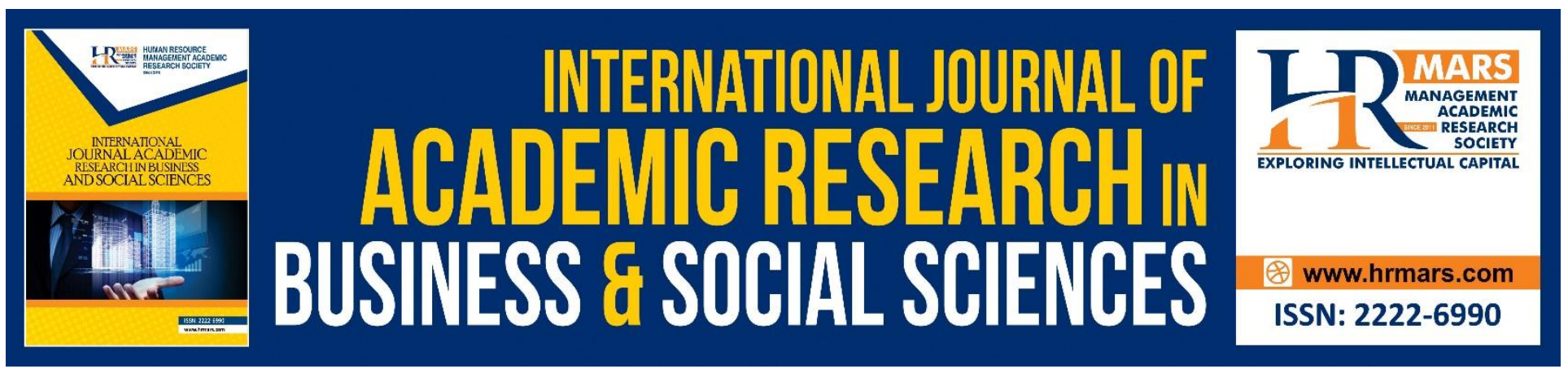

\title{
Managerial Ownership and Financial Performance of Listed Manufacturing Firms in Nigeria
}

\author{
SAIDU, Sani Alhaji \\ Accounting Department, Adamawa State University, Mubi \\ Email: Sanisaidu1987@gmail.com \\ GIDADO, Sani \\ Accountancy Department, Modibbo Adama University of Technology, Yola \\ Email: Sanigidado75@gmail.com
}

\begin{abstract}
The study aimed at investigating the effect of managerial ownership on financial performance of listed manufacturing firms in Nigeria. The non-survey method of research was adopted where data were generated from annual reports and accounts of listed manufacturing firms in Nigeria. The study cover the forty (40) manufacturing firms quoted on the floor of Nigeria Stock Exchange (NSE) as $31^{\text {st }}$ December, 2016 out of which ten (10) were selected as sampled size. The technique of analysis adopted for this study was correlation and OLS regression techniques. The study found that managerial ownership has negative and significant impact on financial performance of listed manufacturing firms in Nigeria. The study concludes that managerial ownership impact negatively on the financial performance of manufacturing firms listed in Nigeria as managers of firms sometimes manipulate the accounting numbers in the financial statement in order to have a private gain. The study then recommends that the board of directors in the Nigerian manufacturing firms should ensure that shareholding of the insider managers is not too high and the proportion of their shareholding should be minimize in other to better the performance of manufacturing firms listed in Nigeria.
\end{abstract}

Keyword: Managerial Ownership, Financial, Performance, Manufacturing, Firms

Introduction

Business organizations are formed with the sole purpose of making profit which usually depends on their decision-making mechanisms. Corporate decisions also affect its capital base and the plans of either going for equity financing or debt financing (leverage). In debt financing, companies normally borrow capital and resources from external sources (Honeine \& Swan, 2010). There has been a great 
INTERNATIONAL JOURNAL OF ACADEMIC RESEARCH IN BUSINESS AND SOCIAL SCIENCES Vol. 8, No. 9, Sept. 2018, E-ISSN: 2222-6990 @ 2018 HRMARS

paradigm shift in the corporate governance arena as more and more organizations integrate the ownership structure ideology into their operations to source capital.

The separation of ownership and control in Modern Corporation introduced by Berle and Means (1932) retains a central position in the economic theory of the firm. They claim that separation of ownership from control produces a condition where the interest of owner and ultimate manager may conflict. Every firm has several ways of building its ownership. Normally the type of ownership structure a firm decides to adopt is engineered by the vision of the company. Hubbard (1996), Corporate Governance made an important effort to ensure accountability and responsibility and a set of principles, which should be incorporated into every part of the organization.

Ownership structure is the distribution of equity capital as well as the identity of the equity owners. These structures are of major importance in corporate governance because they determine the incentives of managers and there by the economic efficiency of the corporations they manage (Jensen \& Meckling, 1976). Corporate governance framework is the widest control mechanism (both internal and external) since it encourages the efficient use of corporate resources and ensures accountability for the stewardship of those resources utilized (Imam \& Malik 2007). Lins (2002) further opined that corporate governance could help to align the interests of individuals, corporations and society through a fundamental ethical basis and will fulfill the long-term strategic goal of the owners, building shareholder value and establishing a dominant market share.

Managerial equity holding may increase corporate performance because it means better alignment of the monetary incentives between the manager and other equity owners (Jensen \& Meckling, 1990). More equity ownership by the manager may increase corporate performance because the managers are more capable of opposing a takeover threat from the market for corporate control and as a result, the raiders in this market will have to pay higher takeover premiums (Fosberg 1989). However, managers who have an interest in the corporations may be more active and try to protect the organizational interest in all stake, this is because they should have the feeling and thinking that the failure of the organization impliedly is their failure and that may cause them loose their equity holding. On the other hand managers with a shareholding in an organization will strive to improve the performance of an organization in other to earn them a high return inform of dividend, bonus issue etc.

Several attempts in the literature have tried to explain this relationship focusing the attention to the information asymmetries between managers and owners in the firm decision-making process. On the one hand, the literature pointed that large shareholders have strong incentives in profit maximization and enough control over the assets of the firm to put pressure on managers to have their interest respected and risky projects maintained (Shleifer \& Vishny, 1997). In the same line, some studies explain that the concentration of capital in a small number of owners helps to align the management team with the shareholders' interests, leading to reducing high risk investment policies such as the ones of innovation, and to a loss of some of the benefits of specialization (Hill \& Snell, 1989; Burkartet al., 1997). The researchers observed that firms' with high concentrated shareholding in a hands of small number of individuals benefit better by avoiding highly risk investment decisions and help mitigate the conflict of interest between owners and management, because block holders are more powerful in influencing management decisions. 
INTERNATIONAL JOURNAL OF ACADEMIC RESEARCH IN BUSINESS AND SOCIAL SCIENCES Vol. 8, No. 9, Sept. 2018, E-ISSN: 2222-6990 @ 2018 HRMARS

Managers of corporate entities are much concerned on how to achieve high financial performance as it has long-term effect on their corporate set-ups which ranges from utilization of limited resources at their disposal, wealth maximization and repayment of debt and interest charge (Kakanda 2016). There are different viewpoint on performance by interested parties in an organizations especially shareholders who are interested in profitability and managers on the other hand are interested in the growth of the company. In this regard both profitability and growth should be considered while analyzing performance of a company as performance is believed to be a cardinal key in determining the perpetuity of a business set up which is regarded as the foremost objective of profit-oriented organizations.

Performance is used to mean the efforts extended to achieve the targets efficiently and effectively which involves the integrated use of human, financial and natural resources so also as well as the presentation of quality result achieved by the management of company as utilization of different levels of equity and debt by managers is one of the strategy used by firms to improve their financial performance (Gleason et al., 2000). Financial performance is the scientific evaluation of profitability and financial strength of any business concern as financial statement analysis attempt to unveil the meaning and significance of the items composed in income statements and statement of financial position which will assists management in the formation of sound operating and financial policies.

The manufacturing sector plays a significant role in the development of every economy. According to Mike (2010), the manufacturing sector is expected to dominate, shape and define the core path of industrialization all over the world. The sector is reputed to be an important engine of growth, an antidote for unemployment; a creator of wealth and the threshold for sustainable development, yet, the sector is also confronted with series of problems that led to the high mortality rate of manufacturing outfits. A clear example was the accounting scandal by Cadbury Nigeria plc where the company's share price declined from N86.52 per share as at December, 2005 to N8.65 as at October, 2009. This scandal according to Okaro and Okafor (2013) has since been euphemistically dubbed as Nigerian's Enron equivalent.

Despite the existence of many corporate governance mechanism a lot of corporate failures and financial scandals (Cadbury Nigeria plc and Oceanic bank, intercontinental Bank etc) were perpetrated by the management of both financial and non-financial firms in Nigeria. This therefore brought about doubt in the minds of shareholders and investors on the credibility and reliability of financial reporting. It was as a result of these corporate failures that the researchers considered it of paramount importance to investigate the effect of ownership structure on the financial performance of listed manufacturing firms.

Moreover, the Nigerian capital market has witnessed a dramatic decline in performance which was a result of firm declining performance where several firm especially the Nigerian banking sector. This financial crisis entirely discourages the confidence of both domestic and international investors to invest in the Nigerian stock market. This situation sparked an intensive debate, which sought to explain the cause of such deterioration. One of the fundamental cause of such deterioration within the firms has been attributed to the ineffectiveness of the corporate governance system and its mechanisms particularly ownership structure (Shehu, 2011).

The Nigerian manufacturing firms is one of the sensitive sub-sector for economic growth and development, therefore, it should be a sector expected to be monitored seriously so that to prevent 
abusive accounting practices which may not be in favor of the shareholders, investors and any other stakeholders that uses financial reporting and the industry itself. This is because firms in this sector produce normally domestic commodities consume normally for domestic households, as such significant amount of revenue sales is generated. Thus, government source a significant amount of revenue as tax and this firms are encourage by government to avoid collapse of the sector (Dalton, 1986). However, this has not been so because Nigeria's manufacturing sector has been operating under very unfavorable environments and has a little contribution to the nation's GDP. And many firms had closed down due to lack - of patronage of their products both in Nigeria and beyond as for every to be industrialized is should have a developed and vibrant manufacturing sector. Such a sector will generate massive employment, fight poverty, create wealth, and enhance exports and diversify foreign exchange earnings. Hence, studying ownership structure and financial performance of listed manufacturing firms in Nigeria will be of interest to all the stakeholders.

\section{Literature Review}

The related concepts and several empirical literatures were reviewed to show the expected relationship and impact of the dependent variable and the explanatory variable of the study coupled with study related theories.

\section{Corporate Governance}

Corporate governance is a term that is frequently used by researchers, practitioners, the media, regulators, and the general public, all focusing on control mechanisms. Typically the term corporate governance means to mitigate conflicts of interest between managers and investors (Bjuggren, 2007)). However it has not been possible to find general agreement on the definition of concept of corporate governance. Cebenoyan et al.(2000) argued that a comprehensive definition of corporate governance is difficult because it covers a broad governance structures (board of directors, shareholders, audit committee, compensation contracts, etc.). Hence, narrowing the definition is problematic since it limits the focus and interpretation of the role of governance mechanisms. However, in defining corporate governance, a distinction between internal or external control mechanisms is broadly used in literature (Coles et al., 2001; Denis and McConnell, 2003; Cuiet al., 2004). Monitoring by the board of directors and controlling shareholders and the use of incentive compensation (i.e., performance-based compensation) are considered as internal governance mechanisms; whereas disclosure requirements, corporate laws for investor protection, and monitoring by creditors and independent directors, are considered as external monitoring mechanisms in literature.

\section{Managerial Ownership}

Separation of ownership and control and the conflicts of interests between the agent (managers) and the principal (owners) (Jensen and Meckling, 1976) are often the main focus of the corporate governance literature. However, a narrow definition of corporate governance, which only focuses on the classic agency conflict between managers and shareholders, ignores the potential conflicts of interest among other parties (Cornet et al., 2007). Hence, delegating the responsibility of monitoring management to the board of directors may lead to another agency conflict between the board of 
directors and shareholders (Edward et al., 1999). Accordingly, boards of directors may avoid efficient monitoring because they are dependent on managers or simply because they do not have an incentive to put much effort in monitoring managers.

However, it is true that monitoring by regulators represents an additional governance mechanism, their presence may further complicate governance problems in firms. Thus, the presence of heavy regulations, informational asymmetries, sequences and a conflict of stakeholder interests in firms a special relevance on the internal corporate governance mechanisms which has the board of directors at its apex.

According to Loderer and Martin (1997) Managerial ownership is a situation where the manager owns shares in the firm they manage, in other words they serve as managers of the firm and as well as the company's shareholders. The definitions above look at the possession of shares from insider perspective which is not different from the shares held by those at the helm of affairs, (the managers of the company). This implies that, managerial ownership means the amount of share either in naira amount or units of shares held by those who manage the affairs of the business where they act as an agent of the public (shareholders). The opposing effect of managers become owners is that they also gain voting power as they will be involved in manipulation of results to make it look like the firm is operating better (Krivogorsky, 2006). Managerial ownership can provide a direct economic incentive for managers to engage in active monitoring and also align ownership and control through meaningful directors' stock ownership.

Managerial shareholding is the portion of equity shares held the managers of an entity and the reason behind discussing this corporate attribute is nothing more than the agency theory which assumes that managers that are actively participating in the managing the affairs of an entity tends to act in a way that will maximize the value of firms. Furthermore, in reference to the conflict of interest between owners and managers or 'agency problem' (resulting from the separation of owners and manager), several studies focus on the way to 'control' managers to work in the shareholders' interest. Most of them suggest that concentrated ownership directs a firms' management effectively and mitigates agency problem. Alternatively, Jensen and Meckling (1976) suggest that when managers hold a proportion of shares in firms, the interest of shareholders and managers are aligned and the conflict between them declines. In this regard, managers are less inclined to divert resources towards their own accounts. Moreover, with a higher proportion of shares in the hands of managers, they will work harder to improve the firm performance, which will increase the value of the firm and consequently the managers' wealth.

\section{Financial Performance}

Performance is crucial to any business organisation survival and continues patronage by investors, potential investors, potential investors, creditors, and other stakeholders in the business world. Every business organisation has an important decision of making returns. This decision is important since the ability of a firm to make returns in this competitive environment determines to a larger extend its ability to survive in the future. However, managers of corporate entities are much concerned on how to achieve high financial performance as it has a long-term effect on their corporate set-ups which ranges from management efficiency (utilization of limited resources at their disposal); 
INTERNATIONAL JOURNAL OF ACADEMIC RESEARCH IN BUSINESS AND SOCIAL SCIENCES Vol. 8, No. 9, Sept. 2018, E-ISSN: 2222-6990 @ 2018 HRMARS

investors goal (wealth maximization) and lenders driven (repayment of debt and interest charge thereon).

The financial performance of a firm can be analyzed in terms of profitability, dividend growth, sales turnover, asset base, capital employed among others (Almajali et al., 2012). However, there is still debate among several disciplines regarding how the performance of firms should be measured and the factors that affect financial performance of companies (Liargovas and Skandalis, 2008). The study adopted return on Asset (ROA) as a measure of financial performance as it considered the profitability aspect of firm performance.

Return on assets (ROA) is also a measure of performance widely used in the governance literature for accounting-based measures (Weir \& Laing 2001 \& Nicholson 2003). It is a measure which assesses the efficiency of assets employed (Bonn, Yoshikawa \& Phan 2004) and shows investors the earnings the firm has generated from its investment in capital assets (Epps \& Cereola, 2008). Efficient use of a firm's assets is best reflected by its rate of return on its assets. ROA is an indicator of short-term performance which is calculated as net income divided by total assets (Finkelstein \& D'Aveni, 1994). Since managers are responsible for the operation of the business and utilization of the firm's assets, ROA is a measure that allows users to assess how well a firm's corporate governance system is working in securing and motivating efficiency of the firm's management (Epps \& Cereola, 2008).According to agency theory, managers are likely to exploit the available resources to their own interest, leaving less return to shareholders. Thus, ROA is a measure of operating performance directly related to the earnings management has generated from the efficient use of a firm's assets, which effectively belong to shareholders. Higher ROA indicates efficiency on the part of management's ability to use firm's assets to maximise shareholders' investment given effective corporate governance mechanisms in place. In contrast, lower values of ROA suggest less effective management and governance mechanisms in place. However, the reliance on ROA as an accountingbased firm performance measure has been criticised on the grounds that the accounting earnings used may not reflect economic earnings and the book value of assets may not reflect the market values (Owusu, 2012). This means that the accounting earnings and the book value of assets under the control of management may be subjected to managerial manipulations which could result in overstatement of earnings and understatement of assets due to changes of accounting policies relating to depreciation, inventory valuation, treatment of certain revenue and expenditure. It is assumed that the higher the value of ROA, the more effective the governance mechanisms and the better the management's ability to generate returns for shareholders' investment of the firm.

\section{Empirical Framework}

Zhou and Wang (1999) in a research review the relationship between ownership structure and corporate governance in China exchange and the study concluded that institutional investors have a positive impact on firms profitability. Clay (2001) finds a positive impact of institutional ownership on firm performance in which a percentage increase in institutional ownership translates into a 0.75 percent firm performance enhancement. Selecting the 1,914 firms included in Standard \& Poor's from 1992 through 1997.

Sanda, Mika'ilu and Garba (2005) posited that director's shareholding is significantly negatively related to firm performance. This compares with outside directors and ownership concentration, 
INTERNATIONAL JOURNAL OF ACADEMIC RESEARCH IN BUSINESS AND SOCIAL SCIENCES Vol. 8, No. 9, Sept. 2018, E-ISSN: 2222-6990 @ 2018 HRMARS

which are not significant in all cases. This finding also does not support Anderson et al., (2000), who saw no significant relationship between firm performance and insider ownership. In addition, McConnell and Servaes (1990) credited a significant curvilinear relationship between insider ownership and firm performance. On the other hand a non-significant relationship exists in the work of (Loderer \& Martin 1997). Managerial ownership has negative and strong impact on firm performance of study with 8 sample firms (Faruk \& Mailafia 2013).

Kaserer and Moldenhauer (2005) address the question whether there is any empirical relationship between corporate performance and insider ownership. Using a data set of 245 Germen firms for the year 2003 they find evidence for a positive and significant relationship between corporate performance, as measured by stock price performance as well as by Tobin"s Q, and insider ownership. Mueller and Spitz (2006), analyze the relationship between managerial ownership and performance of German SMEs with motivational hypothesis testing, in their research. They use a sample of 356 firms in services sector that are associated with business in their research, for the years 1997 to 2000. The findings show that performance of companies with managerial ownership percentage, above 40 percent, is being improved (Mueller \& spitz, 2006).

Belkhir, (2006) used simultaneous equations on a sample of US banks and the study didn't find a significant effect of dominant ownership in bank performance. Hanafi et al (2010) found from a sample of 54 commercial banks in Indonesia through the period (2002-2008) that the concentration ownership has a negative impact on bank performance. On the other hand Wen, (2010) showed a positive relationship between ownership concentration and bank performance in China.

Mueller and Spitz (2006) focus on the relationship between managerial ownership and small and medium-sized private enterprises operation in Germany the study findings show that performance, measured by survey-based profit information, is increasing in managerial ownership by up to around 40 percent. However, Kapopoulos and Lazaretou (2007) assess the impact of the structure of ownership on corporate performance, measured by profitability, using data for 175 Greek listed firms their research results show that there is a positive and significant relationship between more concentrated ownership structure and firm profitability.

Wang et al. (2009) review the effect of ownership structure features on Chinese firms operations. They note two approaches of ownership structure in their research. First they review the impact of each one of ownership structure characteristics on firms' performance then thy review the impact of all ownership structure characteristics on firms performances. They concluded that the firms that have the better ownership structure mechanism also have a better performance and valuation .Also there is a positive and significant relationship between ownership concentration, managerial investors' state ownership and firm performance and its market value.

Hasnain (2010) studied that relation between ownership and divided policy of Karachi stock exchange. Data of the companies was obtained for the period of 2002 to 2006. They measured ownership structure as percentage of shares held by directors (only). The result shows that there is a positive and significant relationship of ownership structure and dividend policy. He stressed that this reduces the agency conflict and developed the trust of the outsiders and shareholders of the company. He concluded that in developed market where ownership is highly varying, the market power may force the management to distribute dividends and to meet the demand of the investors. 
INTERNATIONAL JOURNAL OF ACADEMIC RESEARCH IN BUSINESS AND SOCIAL SCIENCES Vol. 8, No. 9, Sept. 2018, E-ISSN: 2222-6990 @ 2018 HRMARS

Sehrish and Afzal (2010) applied OLS, Logit and Probit regression and found that insiders "ownership (management ownership) and profitability show significant negative impact on dividend payment. While the result of logit and probit model show that individual ownership and insider ownership are negatively related with dividend policy but, profitability is positively significant relates to with dividend structure. Shariff, Salehi, and Bahadori (2010), analyzed the influence of shareholders" ownership on payout ratio. They found a significant positive correlation between institutional ownership and payout ratio.

Garcia et al. (2011) review the relationship between ownership structure and the accuracy of their earnings forecasts. The ownership structure examined in this study includes the concentration of ownership, bank ownership and external ownership. They use the absolute value of the difference between the real earning and predicted earning divided by actual profit. The study findings indicate a significant relation between bank ownership and Earning Forecast Accuracy (EFA), with ownership concentration and managerial ownership having no significant impact on EFA. While Lina, Suzan, Ola, and Imad (2012) investigated the effect of ownership structure on dividend pay-out policy of Jordanian industrial public companies for the period 2005-2007. The statistical result consistently supports a significant positive impact of foreign ownership on dividend pay-out policy.

Gugong, Arugu, \& Dandago (2014) examined the impact of ownership structure on the financial performance of listed insurance firms in Nigeria. The study uses panel data for seventeen (17) firms for the period 2001 - 2010 (10 years) the study Found that there is a positive and significant relationship between ownership structure and firm's performance as measured by ROA and ROE. Also Aymen, (2014); studied the impact of ownership structure on financial performance of 19 sampled banks in Tunisia for the period (2000-2010). The study found that there was no impact of ownership structure on financial performance of banks in the Tunisian.

Ibrahim, (2016) Investigated the impact of ownership structure on dividend policy of listed Deposit Money Banks (DMBs) in Nigeria for the period 2010-2014. The study found that managerial ownership and ownership concentration are likely to have significant negative impact on dividend policy of listed DMBs in Nigeria, while institutional ownership is found to have likely significant positive impact on dividend policy of listed DMBs in Nigeria. But foreign ownership is found not to have likely significant impact on dividend policy of listed DMBsin Nigeria.

Wahyu, Budiyanto, Sutjipto and Nur, (2016) examine the role of the ownership structure on capital structure and company's financial performance of non-financial companies in Indonesia for the period 2009-2014. The results indicate that Capital structure have negative and significant impact on company's financial performance while Institutional ownership and managerial ownership does not contribute to the effects of capital structure on a company's financial performance. Kakanda, et al., (2016). Assessed the effect of capital structure on the financial performance of listed Consumer goods companies in Nigeria for the period 2008 - 2013 and the study found that there is a positive and significant relationship between firm's capital structure and corporate financial performance

Yaghoobi, A. \& khansalar, E. 2016) Investigated the relationship between ownership structure and economic performance criteria of companies listed on Tehran Stock Exchange. The study found that there is a significant relationship between Institutional ownership and property management and economic value added and modified economic value added but there is not any relationship between ownership concentration variable and economic performance criteria. 
INTERNATIONAL JOURNAL OF ACADEMIC RESEARCH IN BUSINESS AND SOCIAL SCIENCES Vol. 8, No. 9, Sept. 2018, E-ISSN: 2222-6990 @ 2018 HRMARS

Finally, after reviewing most of the prior studies in relation to ownership structure of financial performance the researcher observed that most of the studies both at international and national level were conducted in other sectors of the economy such banks, insurance, conglomerate, oil and gas, consumer goods among other neglecting the manufacturing firm even though the sector plays a key role in development as industrialization is one of the development yardstick of countries (see appendix 3). Therefore, considering the aforementioned the study deems it necessary to fill the gap by studying the impact of ownership on financial performance of sampled manufacturing firms in Nigeria.

\section{Theoretical Review}

Several theories mostly used by researchers to explain the impact corporate governance mechanical specifically ownership structure and financial performance by explaining the mix of financing sources used by firms were reviewed, determinants of ownership structure and the link between ownership structure and firm value. The theories discussed in this study are agency MM, trade-off, stakeholders, stewardship, pecking order and market timing theory and the study finally adopt agency theory as explained thus:

Agency theory becomes a formal concept after the work of Jensen and Meckling (1976). They argue on a philosophy that corporations are always structured to minimize the costs of getting agents (agency cost) to follow the interest of the principal, since the corporation are not always run by the principal. The theory clearly pointed out that different parties involved in the same situation with same objective will have different motivations. This means that agent will always have the power of information thereby creating information asymmetric between the agent and the principal. However, because efficiency and effectiveness are inseparable there will be conflict of interest within and among the parties.

Furthermore, where one or more persons stand to delegate one or more persons to act and make decisions on their behalf contractual relationship is said to exist. Agency theory is therefore concerned with contractual relationship between two or more persons called the agent(s) to execute some functions on behalf of their boss's principal(s). Both the parties are expected to have entered a mutual agreement which is solely motivated by self interest. Specifically agency theory describes the relationship between one party, (principal) whose delegate's responsibility to another person, (agent). It explains their differences in behavior or decisions by nothing the two parties often have different goals and, independent of their respective goals, different attitude towards risk. Invariably, the agents' decision choices are assumed to have effect on both parties. These relationships, according to Bjuggren et al., (2007), are perceived in economic and business life and also generate more problems of contracting between entities in the economy. This means that there is a contractual relationship between shareholders.

Considering earnings management practice, agency theory explains clearly the existence of the incentive for management to use earnings management. Therefore, management could use earnings to mislead shareholders by showing a different image of the company's earnings as reported in the company's financial reports. Additionally Sunday et al., (2012) pointed out that earnings management may arise as a result of information asymmetry or problem of agency conflicts that occur when equity ownership is separated from the management of the corporation and managers 
have a comparative information advantage over shareholders and that this market imperfections create an environment for managers to engage in accounting discretion in order to promote their selfish interest at the expense of shareholders which consequently affect performance. At the same time, they also create an opportunity for managers to use that accounting discretion to portray their companies' good image related information in appropriate manner with investors.

However, because of the opportunities tendencies of managers (agents) it becomes of paramount importance for corporations to provide some mechanisms that will serve as a watchdog to mitigate the gap that exist between the interest of agents and that of the principal. In this regard, ownership structure of which; managerial ownership, institutional ownership concentration and foreign ownership are integral part that serves as an effective and efficient mechanisms or tool in achieving the expectations and the need of shareholders (principals), thereby providing better and effective monitoring of managers (agent) which serves as an impetus of transparent and reliable reporting for improve performance.

While the other aspect of the agency theory are the management (agents) who are responsible for the preparation and fair presentation of financial statements in accordance with Nigerian Statement of Accounting Standard (SAS) they also assumed to make sure that the financial statements are free from material misstatement, whether due to fraud or error. Agency theory provides a natural backdrop for analysis because financial reporting concerns arise when there is a conflict of interests between managers and owners (shareholders) coupled with information asymmetries Beatty and Harris (1998), Kim and Yi (2006), and Richardson (2000). Without this agency problem, financial performance is a non-issue because managers do not have any incentive to misreport or hide information (keeping aside reporting incentives that might arise from strategic product market considerations). The study adopted agency theory as the underpinning theory that best explain the study because the purpose of corporate governance in its various forms is to reduce this agency problem, suggesting a natural link between ownership structure and financial performance as effective corporate governance should result in high financial performance.

\section{Methodology}

The study adopted survey research design as it uses panel data mainly from secondary sources because it is a quantitative study with positivism paradigm and the core of the data needed for analysis were adequately and conveniently extracted from the audited financial reports and accounts of the sampled manufacturing firms in Nigeria for the period 2007 to 2016. The population of the study consist of all 40 listed manufacturing firms in the Nigerian Stock Exchange as at $31^{\text {st }}$ December 2016 (See appendix 1). However, the sample was drawn from the manufacturing firms quoted on the floor of Nigeria Stock Exchange (NSE) using a purposive sampling technique through filtering of two point criteria. The criteria is the prospective sample firm must have available and complete data and information needed for measuring the variables within the period of the study (2007-2016) and the firm must be on the trading floor of the NSE within the period of study. Strict adherence to these criteria resulted in the emergence of ten (10) manufacturing firms as the sample for the study (see Appendix 2). The panel multiple regressions was used to determine the causality effect of the managerial ownership (independent variable) measured proportionate number of shares owned by manager on financial performance (dependent variable) measured by return on asset. 
INTERNATIONAL JOURNAL OF ACADEMIC RESEARCH IN BUSINESS AND SOCIAL SCIENCES

Vol. 8, No. 9, Sept. 2018, E-ISSN: 2222-6990 @ 2018 HRMARS

The following is the model used to empirically test the data collected.

$\mathrm{PERF}_{\text {it }}=\beta_{0}+\beta_{1} \mathrm{MGO}_{\text {it }}+\varepsilon_{\text {it }}$

Where:

MGO = Managerial Ownership

$P E R F=$ firm financial performance

$\beta 0=$ Constant

$\beta 1=$ coefficient of the parameters

$\varepsilon=$ error term

\section{Result and Discussion}

The section starts with analyzing the trend of the variables using descriptive statistics followed by the presentation and analysis of the correlation matrix and finally presentation and discussion of the regression result.

\section{Descriptive Statistics}

The Table 4.1 present the descriptive statistics where minimum, maximum mean, standard deviation, skewness and kurtosis of the data for the variables used in the study are described.

Table 4.1: Descriptive Statistics

\begin{tabular}{|l|l|l|l|l|l|l|}
\hline Variable & Mean & Minimum & Maximum & Std. Dev & Kurtosis & Skewness \\
\hline ROA & 0.0863126 & 0.127998 & 0.2233526 & 0.0418433 & 4.065282 & 0.9657624 \\
\hline MGO & 0.2121364 & 0.233071 & 0.7659693 & 0.160553 & 3.504946 & 0.7317345 \\
\hline
\end{tabular}

Source: Stata Output, 2016

Table 4.1 shows that the measure of financial performance, return on asset (ROA) of the manufacturing firms listed in Nigeria has a mean value of 0.0863126 with standard deviation of 0.0418433 , and minimum and maximum values of 0.127998 and 0.2233526 respectively. This implies that, the average performance in manufacturing firms in Nigeria is 0.0863126 to 0.2233526 , and the deviation from both sides of the mean is 0.0418433 . This suggests that, the dispersion of the data from the mean is too wide because the standard deviation is higher than the mean value. The table also indicates a minimum ROA of 0.127998 implying a situation in which the return on asset did not cover much portion of the performance measure in the manufacturing firms sector. The peak of the data is indicated by the kurtosis value of 4.06282, suggesting that most of the values are higher than mean, hence the data did not meet a normal distribution assumption. The coefficient of Skewness of 0.9657624 implies that the data is positively skewed (most of the data are on the right hand side of the normal curve); thus, the data does not meet the symmetrical distribution assumption.

The Table 4.1 indicates an average proportion of shares held by managers (MGO) of 0.2121364 with standard deviation of 0.1560553 , the minimum and maximum values is 0.233071 and 0.769693 respectively. This implies that, on average, the proportion of shares held by MGO in manufacturing sector is $21 \%$ and the data deviate from both sides of the mean by $15 \%$. This suggests a wide dispersion of the data from the mean because the mean is higher than the standard deviation. The peak of the data is indicated by the kurtosis value of 3.504946, suggesting that most of the values are 
INTERNATIONAL JOURNAL OF ACADEMIC RESEARCH IN BUSINESS AND SOCIAL SCIENCES

Vol. 8, No. 9, Sept. 2018, E-ISSN: 2222-6990 @ 2018 HRMARS

higher than mean, and the data did not meet a normal distribution assumption. The coefficient of Skewness of 0.7317345 implies that the data is negatively skewed (that is, most of the data are on the left side of the normal curve), implying that the data do not meet the symmetrical distribution assumption.

\section{Correlation Matrix}

The subsection presents the correlation matrix table where the relationship of the independent variable and the dependent variable is analysed as shown on the table 4.2

Table 4.2: Correlation Matrix

\begin{tabular}{|l|l|l|}
\hline Variables & ROA & MGO \\
\hline ROA & 1.0000 & \\
\hline MGO & -0.3270 & 1.0000 \\
\hline
\end{tabular}

\section{Source: Stata Output, 2016}

The results in Table 4.2 show the degree of association between financial performance as represented by return on asset (ROA) and all pairs of independent variables individually between themselves and cumulatively with the dependent variable (ROA) of the study in the manufacturing firms listed in Nigeria. The table presents a negative relation between financial performance (ROA) and managerial ownership (MGO) from the correlation coefficient of -0.3270 . This relationship implies that, as the proportion of MGO increases the ROA of the sample firms will decrease.

\section{Presentation, Analysis and Discussion of Regression Results}

This section presents the regression result of the dependent variable (ROA) and the independent variable of the study managerial ownership which follows with the analysis of the association between dependent variable and the independent variable. Hence, the summary of the regression result obtained from the model of the study $\left(\boldsymbol{P E R} \boldsymbol{F}_{i t}=\boldsymbol{B}_{\boldsymbol{0}}+\boldsymbol{B}_{1} \mathbf{M G O} \boldsymbol{O}_{i t}+\boldsymbol{\varepsilon}_{i t}\right)$ is presented in table 4.3 below:

Table 4.3 Regression Results

\begin{tabular}{|l|l|l|l|}
\hline Variables & Coefficients & z-values & p-values \\
\hline MGO & -3.312994 & -4.48 & 0.000 \\
\hline Intercept & 2.879923 & 5.83 & 0.000 \\
\hline $\mathbf{R}^{\mathbf{2}}$ & & & $\mathbf{0 . 6 6}$ \\
\hline F-Statistics & & & $\mathbf{3 7 . 7 1}$ \\
\hline F-Sig & & & $\mathbf{0 . 0 0 0 0}$ \\
\hline
\end{tabular}

\section{Source: Stata Output, 2016}

Table 4.3 shows that the managerial ownership has a z-value of -4.48 with a beta coefficient of 3.312994 which is statistically significant at $1 \%$ significance level. This indicates that, managerial ownership has negatively, strongly, significantly and statistically impacted on the performance of listed manufacturing firms in Nigeria. This further explained that for every $1 \%$ increase in the shares held by managers of manufacturing firms listed in Nigeria, the performance of the firm will decrease. 
The result is not surprising as managers always tend to satisfy their interest first to the detriment of the firms, despite the fact that they have shareholding in the company. In addition the entrenchment effect argument put forward by the Jensen \& meckling (1976) that, mangers of firms tends to manipulate the accounting numbers in the financial statement in order to have a private gain. Thus, the finding validates the Agency theory that conflict of interest do exist between the managers (Agent) and the Principals. However the result is in line with reality of practice by some managers where they rank their selfish interest first to the detriment of the firm objective. Thus, the policy implication derivable from this finding is that, the management of manufacturing firms of Nigerian should define a percentage limit of shares beyond which managers should not hold. The findings also provide an evidence of rejecting the first null hypothesis of the study that managerial ownership has no significant impact on the financial performance of manufacturing firms listed in Nigeria. The finding is in line with Sandaet al (2005), Farouk et al (2013).

The cumulative $R^{2}(0.66)$ which is the multiple coefficient of determination gives the proportion or percentage of the total variation in the dependent variable as explained by the independent variables jointly. Hence, it signifies $66 \%$ of total variation in financial performance as measured by the return on asset (ROA) of manufacturing firms listed in Nigeria is caused by the effort of managerial ownership. This further indicates that the model is fit and the variable were properly selected, combined and used in the study. This is statistically supported by the F- statistic coefficient of 37.71 with a $p$-value of 0.0000 which is statistically significant at $1 \%$ level of significance. The study found that managerial ownership (MGO) has negative and significant impact on the performance of listed manufacturing firms in Nigeria as shown by the z-value of -4.48 and a beta coefficient of -3.312994 which is statistically significant at $1 \%$ significance level.

\section{Conclusion and Recommendation}

Based on the discussion and analysis of the result presented, the study concludes that the study has provided both empirical and statistical evidence on the utility of explanatory variable that managerial ownership impact negatively on the financial performance of manufacturing firms listed in Nigeria as managers of firms sometimes manipulate the accounting numbers in the financial statement in order to have a private gain.

In line with the finding and conclusion of the study, the study recommends that the board of directors in the manufacturing firms in Nigeria should ensure that shareholding of the insider managers is not too high in such a way that the proportion of their shareholding should be minimal which should not exceed $10 \%$ of the total shareholding in the company as it was found being among the factors that reduces firms performance.

\section{References}

Almajali, A.Y., Alamro, S.A., Al-Soub, Y.Z. (2012), Factors affecting the financial performance of Jordanian insurance companies listed at Amman stock exchange. Journal of Management Research, 4(2), 266-289

Amran, N.A., Ahmad, A.C. (2009), Family business, board dynamics and firm value: Evidence from Malaysia. Journal of Financial Reporting and Accounting, 7(1), 53-74. 
INTERNATIONAL JOURNAL OF ACADEMIC RESEARCH IN BUSINESS AND SOCIAL SCIENCES Vol. 8, No. 9, Sept. 2018, E-ISSN: 2222-6990 @ 2018 HRMARS

Belkhir .M ( 2006) “ Board structure, ownership structure and firm performance : evidence from banking "Applied Financial Economics, 19(1) 1581-1593.

Bonn, I., Yoshikawa, T., \& Phan, P. H. (2004), 'Effects of Board Structure on Firm Performance: A Comparison between Japan and Australia', Asian Business \& $\quad$ Management, 3(1)105-125. Cebenoyan, A.S., Cooperman, E.S. \& Register, C.A. (2000), "Managerial Stock Ownership as a Corporate Control Device: When is Enough, Enough?",SSRNe-Library, .

Clay, D.G (2001) "Institutional ownership, CEO incentives and firm value" Paper presented at the AERC biannual research workshop, Nairobi. Kenya.

Coles, J., McWilliams, V., \& Sen, N., (2001), An examination of the relationship of governance mechanisms to performance, Journal of Management, 27(1), 23 -50.

Cornet M.M., Marcus A.J. \& Tehranian H., (2007): Corporate Governance and Pay-for-Performance: the Impact of Earnings Management Journal of Corporate Finance, $\quad 15(1), 412-430$. Dalton, (1986). The Effect of Corporate Governance and Institutional Ownership on Corporate Performance. Academy of Management Journal 42(2), 19-32

Denis, D.K. \& McConnell, J. (2003), "International Corporate Governance", The Journal of Financial and Quantitative Analysis, 38(1), 1-24.

Edwards, J. \& Nibler, M. (1999), "Corporate governance in Germany: the role of banks and ownership concentration", Economic Policy, 15(3), 231- 237.

Epps, R.W., \& Cereola, S.J. (2008).Do Institutional Shareholders Services (IIS) Corporate governance rating reflect a company's operating performance. Critical Perspective on Accounting, 19(2), 1135-1148.

Farouk M.A \& Mailafia M., (2013). Possession structure and firm performance of listed chemical and paints firms in Nigeria. Journal of accounting research and practice, Kaduna State University, ISSN: $2360-8889$

Finkelstein, S., \& D'Aveni, R. A. (1994). CEO duality as a double-edged sword: How boards of directors balance entrenchment avoidance and unity of command. The Academy of Management Journal, 37(5), 1079-1108.

Fosberg, R.H. (1989)., Outside Directors and Managerial Monitoring. Akron Business and Economic Review, 20 (2), 24-32.

Gleason et al., (2000) Audit Committee Characteristics and Executive Committee Characteristic and Firm Performance in Oman: Empirical Study. Asian Social Science, 10(12), 98-113

Gugong B. K., Arugu, L. O. \& Dandago, K.I (2014). The impact of ownership structure on the financial performance of listed insurance firms in Nigeria; International Journal of academic research in accounting, finance and management sciences 4(1)409-416

Hill, C.W.L. \& Snell, S.A. (1989), "effects of ownership structure and control on corporate productivity", The Academy of Management Journal, 32(1), 25.

Honeine, S. \& Swan, P.L., (2010). Is Company Performance Dependent on Outside Director 'Skin in the Game'? [Online] Available at: http://papers.ssrn.com/sol3/papers.cfm?abstract id=1746536

Hubbard, R.G. \& Palia, D. (1996), "Benefits of control, managerial ownership, and the stock returns of acquiring firms", The Rand Journal of Economics, 26(4), 782. 
INTERNATIONAL JOURNAL OF ACADEMIC RESEARCH IN BUSINESS AND SOCIAL SCIENCES Vol. 8, No. 9, Sept. 2018, E-ISSN: 2222-6990 @ 2018 HRMARS

Ibrahim, I. (2016). Ownership Structure and Dividend Policy of Listed Deposit Money Banks in Nigeria: International Journal of Accounting and Financial Reporting 6(1) 1- 19 Imam M. O. \& Mahfuja Malik., (2007), Firm Performance and Corporate Governance through Ownership Structure: Evidence from Bangladesh Stock Market Working Paper 2006-01, Centre for Corporate Governance and Finance Studies, University of Dhaka.

Jensen, M.C. \& Meckling, W.H. (1976), "theory of the firm: managerial behavior, agency costs and ownership structure", Journal of Financial Economics, 3(4), 305.

Jensen, M.C. \& Murphy, K.J. (1990), "Performance Pay and Top-Management Incentives", Journal of Political Economy, 98(2), 225.

Kakanda, M. M., Bello, A. B \& Abba, M (2016). Effect of Capital Structure on Performance of Listed Consumer Goods Companies in Nigeria; Research Journal of Finance and Accounting

7(8) 211- 219

Kapopoulos, P., \& Lazaretou, S. (2007). Corporate Ownership Structure and Firm Performance:

Evidence from Greek Firms. Corporate Governance: An International Review, 15(2), 144-158.

Kaserer Christoph, \& Benjamin Moldenhauer, (2005), "Insider Ownership and Corporate

Performance Evidence from Germany", Working Paper", Centre for Entrepreneurial and

Financial Studies (CEFS) and Department for Financial Management and Capital Market

Kiel, G. C. \& Nicholson, G. J., (2003). Board composition and corporate performance: How the Australian experience informs contrasting theories of corporate governance. Corporate Governance: An International Review, 11(3), 189-205

Kim \& Yi (2006) The impact of corporate governance and board performance on the performance of public listed companies in Malaysia. Ph.D Dissertation, University Sains Malaysia.

Krivogorsky, V. (2006). Ownership, board structure, and performance in continental Europe.

The International Journal of Accounting, 41(2) 176-197.

Lina, W., Suzan, A, Ola, K. \& Imad, A. (2012). The effect of ownership structure on dividend payout policy: evidence from Jordanian context. International Journal of Economics

and

Finance, 4(2), 232

Lins, K.,, (2002), Equity Ownership and Firm Value in Emerging Markets, Working paper, University of Utah.

McConnell, J. \& Servaes, H. (1990). Additional evidence on equity ownership and corporate value. Journal of Financial Economics, 27(2), 595-612.

Modigliani, F \& Miller, M. (1958) Cost of capital, corporation finance, and the theory of investment, American Economic Review 48(3), 655-669

Mueller, E. \& A. Spitz (2006). Managerial Ownership and Company Performance in German Small and Medium-Sized Private Enterprises. German Economic Review, 6(2), 2-18.

Owusu, A. (2012). An empirical investigation of the relationship between corporate governance and firm performance: evidence from Ghana. (Doctoral dissertation). Retrieved from: http://openair.rgu.ac.uk

RAJI, I. (2012) Effects of ownership structure on the performance of listed companies on the Ghana stock exchange (Unpublished Dissertation) submitted to the Institute of Distance Learning, Kwame Nkrumah University of Science and Technology, Ghana. 
INTERNATIONAL JOURNAL OF ACADEMIC RESEARCH IN BUSINESS AND SOCIAL SCIENCES

Vol. 8, No. 9, Sept. 2018, E-ISSN: 2222-6990 @ 2018 HRMARS

Richardson (2000) the impact of ownership structure and board structure on the financial performance: Evidence from Tehran Stock Exchange. Spectrum: a journal of multidisciplinary Research, 1(1), 42-56

Sanda, A., Mikailu, A.S. \& Garba, T., (2005) Corporate Governance Mechanisms and Financial Performance in Nigeria. Research paper 149 Africans Economic Consortium.

Sehrish \& Afzal (2010) Impact of Corporate Governance Mechanism on fim financial performance", African Journal of Business Management, 5 (11), 4143-4151,

Sharif, S.J. S., Salehi, M. \& Bahadori, H. (2010).Ownership structure of Iran evidence and payout ratio. Asian Social Sciences, 6(7),133-151

Shehu, U. H., (2011), Corporate Governance and Finanacial Reporting Quality: A Study of Nigerian Money Deposit Bank, International Journal of Research in Computer

Application and Management 1(6), 12-19

Shleifer, A \& Vishny, R.W. (1997), Large shareholders and corporate control, The Journal of Political Economy, 94(3), 461-488.

Wahyu, A.A., Budiyanto, S. N. \& Nur, F. A. (2016). Ownership structure in the effect of diversification strategy on capital structure and financial performance of companies listed in Indonesia stock exchange, International journal of economics, commerce and management, 6(7), 344-371

Weir, C., \& Laing, D. (2000). The Performance-Governance Relationship: The Effects of Cadbury Compliance on UK Quoted Companies. Journal of Management and Governance, 4, 265-281 Wen, W. (2010) " Ownership structure and bank performance : New evidence in China. Research work September, p3-42.

Yaghoobi, A. \& khansalar, E. (2016) Review of the relationship between ownership structure and economic performance criteria in companies listed on Tehran Stock Exchange International Journal of Economics and Finance; 8(6) 89-99 